International Journal of Mechanical Engineering and Technology (IJMET)

Volume 11, Issue 9, September 2020, pp. 23-32, Article ID: IJMET_11_09_003

Available online at https://iaeme.com/Home/issue/IJMET?Volume=11\&Issue=9

ISSN Print: 0976-6340 and ISSN Online: 0976-6359

DOI: https://doi.org/10.34218/IJMET.11.9.2020.003

(C) IAEME Publication

Scope Database Indexed

\title{
DO LEADERSHIP STYLES IMPACT ORGANIZATIONAL PERFORMANCE IN THE UAE CONTEXT? A STUDY
}

\author{
Dr. Jacob Cherian \\ Associate Professor of Management, Abu Dhabi University, \\ United Arab Emirate (UAE) \\ Dr. Gaikar Vilas B \\ Associate Professor, Department of Economics, Smt. CHM. College, \\ University of Mumbai, India \\ Dr. Paul Raj P \\ Associate Professor and Head Dept. of Economics, \\ Rizvi College of Arts, Science \& Commerce, Bandra (West), Mumbai, India
}

\begin{abstract}
This study was conducted to investigate the relationship between leadership styles and organizational performance. It also examined the impact of different leadership styles on the performance of an organization. This study focused on understanding the effect of Autocratic, Democratic, Laissez Faire, Transactional and Transformational leadership styles on organizational performance in UAE based organization.

The relevant data was collected with the aid of a structured questionnaire which was distributed to 150 respondents. Convenient sampling was used to select the respondents. Pearson correlation was used to examine the relationship between leadership styles and organizational performance. Regression analysis was performed to study the significance of the impact of the different leadership styles on organizational performance.

The study showed that leadership styles have both positive and negative influence on the performance of an organization and that leadership styles alone were responsible for $25 \%$ of organizational performance. The study concluded that Democratic leadership and Transformational leadership had a positive and significant influence on organizational performance in UAE based Organization.
\end{abstract}

Keywords: Leadership; Participative; Autocratic; Democratic; Employee performance. 
Cite this Article: Jacob Cherian, Gaikar Vilas B and Paul Raj P, Do Leadership Styles Impact Organizational Performance in the UAE Context? A Study. International Journal of Mechanical Engineering and Technology. 11(9), 2020, pp. 23-32.

https://iaeme.com/Home/issue/IJMET?Volume=11\&Issue=9

\section{INTRODUCTION}

Leadership plays a critical part in developing an effective organization. It focuses on the development of followers and their needs. Prior literature about leadership portrays it as a personal ability. Messick and Kramer (2004) [20] stated that the extent to which an individual portrays leadership traits depends on the characteristics of the situation and environment in which he finds himself. There are different leadership styles and they differ widely in terms of directing and guiding the employees and subordinates. Many studies have illustrated the inevitable role of leadership in determining organizational performance. This study will analyze a wide range of literature and data to determine the impact of different leadership styles on the organizational performances.

\subsection{Statement of the Problem}

Leadership is unarguably one of the most important factors that influence the performance of an organization. Fiedler (1996) [6], who is well acclaimed for his extensive study of leadership, stated that the effectiveness of a leader is the main determinant of organizational performance. In order to succeed and stay ahead of competitors and to improve organizational performance, organizations need to follow the best leadership styles. However, in this globalized world of multinational companies with a multicultural workforce, it is often difficult to ascertain the most suitable leadership style. Leaders are often inflexible in their leadership style and do not take the changing business and global situations into consideration. This can have a harmful effect on organizational performance. It is in this respect that this study aims to investigate the relationship between the different leadership styles and organizational performance in UAE based company.

\subsection{Aims and Objectives}

\subsubsection{Aim}

The aim of this study is to investigate the impact of leadership styles on the performance of an organization and to find out the most effective leadership style in UAE based organization.

\subsubsection{Objectives}

- To investigate relationship between leadership styles and organizational performance

- To examine the impact that the different leadership style has on the performance of the organization.

\subsection{Scope of the Project}

The scope of the study is centered on the relationship between leadership styles and organizational performance. It will also analyze the impact of leadership styles on organizational performance. Since there are several leadership styles and due to the limitations of time, this study has narrowed down its scope to five main leadership styles namely, Democratic, Autocratic, Laissez-faire, Transformational and Transactional leadership style. 


\subsection{Significance of the Study}

Leadership is one of the most studied and researched subjects of all times. This is due to the inevitable part leadership plays in leading organizations to achieve their goals. There are many leadership styles and it differs from person to person. This study is focused on the relationship between leadership styles and organizational performance. In this highly competitive world, leadership is one of the key determinants of organizational success. So this study will serve as a reference to understand the impact of various leadership styles on organizational performance and determine the most effective leadership styles.

\section{LITERATURE REVIEW}

\subsection{Leadership Style and Performance}

One of the key components in deciding the success of an organization is the type of leadership style it follows. It is generally considered that the leadership style is intended to provide a clear direction and path so that the employees can make their skills and performances more effective. Lee and Chuang (2009), [17] argued that an excellent leader not only ignites a subordinate's potential to enhance efficiency but also achieves organizational goals. Stogdill (1957), [26] explained leadership as the behaviour of an individual to lead a group to accomplish a common goal. Fry (2003), [9] stated that leadership can be used as a leading strategy to inspire and to raise the staff's potential for development and advancement.

There are numerous reasons that pinpoint the relationship between leadership style and organizational performance. The first is that, in today's competitive and dynamic markets, competition is built on innovation, price, organizational performance, decreasing returns and on competencies. Studies have shown that in the midst of these new challenges, successful leadership can improve the performance of organizations. McGrath and MacMillan (2000), [18].

Organizational performance refers to the ability of a firm to attain high profit, quality product, large market share, good financial results, and survival at a fixed time using suitable strategy. (Koontz and Donnell, 1993), [15]

One of the key driving forces of an organization's performance is understanding the effect of leadership on performance. Effective leadership is the vital factor responsible for management development and competitive advantage for organizational performance improvement (Avolio and Yammarino 1999), [1] For instance, transactional leadership helps an organization in achieving their present objectives more efficiently by linking job performance to valued rewards and ensuring that the employees are having the resources required to make sure that the job is carried out (Zhu, Chew and Spengler, 2005), [30]. Visionary leaders create a strategic vision of some future state, communicates that vision by framing and using metaphors, consistently act by modelling the vision, and build a commitment towards the vision (Avolio and Yammarino 1999), [1]

Mehra, Smith, Dixon and Robertson (2006), [19] in their study argue that the effects of leadership come into focus when some organizations look for efficient ways to outperform their competitors. Team leaders are believed to play an important role in the shaping of collective norms, helping groups in adapting to their environments, and coordinating collective action. This leader-centred perspective has provided important insights on the relationship between leadership and the performance of a team. Intangible assets like leadership style, culture, skills and competence, and motivation are seen increasingly as the key sources of strength in those organizations that combine people, processes and organizational performance (Purcell et al., 2004), [23]. 
According to House and Aditya's review (1997) [11] the effects of leadership on the performance of the organization has not been well studied. The current study is intended to reexamine the proposed leadership-performance relationship and, thus, contribute meaningfully to the body of growing literature and knowledge in this area of study.

\subsection{Leadership Styles}

Leadership is the life blood of any organization and its importance cannot be underestimated. Jeremy et al., 2011, [12] in their study viewed leadership style as the combination of traits, characteristics, skills and behaviours that leaders use while connecting with their subordinates. Flippo \& Musinger (1999) [8] see leadership as a pattern of managerial behaviour designed to integrate personal or organizational interest and effect, in pursuit of some objectives. Good leadership is vital for many businesses, governments and organizations Many researchers constructed the idea of the successful performance of the organization under the shadow of a leader (Kouzes \& Posner, 2012), [16] Workplaces require the leadership of experienced and skilled individuals to deliver the guidance and a distinct code of directions for all subordinates to follow (Nelson \& Quick, 2013), [22]

\subsubsection{Autocratic Leadership}

Autocratic or authoritarian leadership is characterized as the individual control; the influential leader takes all the significant decisions with just a little input of the group members of the team. They prefer to make the choices and decides on their perception, ideas, and judgment (Terry, 2015), [27]. They involve absolute, totalitarian control on the group of people. This style is implemented by military, monarchs, and dictators (Daft, 2008), [5]. At times, this style also does not result in the innovative solutions for the problems; ultimately, this can hurt the group performance (Hardman \& Hardman, 2009), [10].

\subsubsection{Democratic Leadership}

Democratic leadership is also known as participative leadership. They listen to the ideas of the group but keeps the decision making the edge on their own side. As the team members play role in the decision-making process, the subordinate's satisfaction and motivation increases (John Kane, 2012), [13]. The shortcoming of democratic leadership style is that it faces problems in a short-term decision-making. Additionally, in those situations where roles and responsibilities are unclear or period to be the essence, they can result in communication disappointments and partial projects (Kane \& Patapan, 2014), [14].

\subsubsection{Laissez-faire Leadership}

Laissez-faire leadership or delegate leadership is a type of leadership style in which leaders are usually laid-back and let the group members in decision-making (Meyer, G. D. and Heppard, K.A, 2000) [21]. When the employees are skilled and can perform by themselves, this leadership style results to be productive. However, Laissez faire leadership is not successful to attain organizational performance in scenarios where individuals are unable to set their goals and responsibilities, manage their projects and solve their problems.

\subsubsection{Transactional leadership}

The transactional leader has the power by the position in the organization, to execute the tasks and gives the rewards or punishments for the team performances. This leadership style provides the prospect to the manager to manage the group performance (Conger \& Kanungo, 1998), [4]. The purpose of the power provided to the leader is to assess, correct and train assistants when he observes that the productivity level of the group members is not up to the 
mark and rewards efficiency and effectiveness when expected effect is grasped (Schein, 2010), [24].

\subsubsection{Transformational Leadership}

The transformation leader always tries to motivate its team to be efficient and effective for the organization (Avolio \& Yammarino, 2013), [1]. This style focuses on the effective communication between the team members. In this approach, the leader is remarkably visible. He focuses on the chain of command in the organization. They focus on the big picture and try to accomplish the task.

\section{RESEARCH METHODOLOGY}

\subsection{Research Design}

The research design is the comprehensive strategy that logically integrates various elements of the study. This study follows an explanatory or a causal research design which is helpful in analyzing the effect of one variable on another. In this study, leadership styles are taken as the independent variables and organizational performance is taken as the dependent variable. The research adopts a quantitative approach in which the data collected through questionnaires is analyzed by using statistical methods.

\subsection{Research Model}

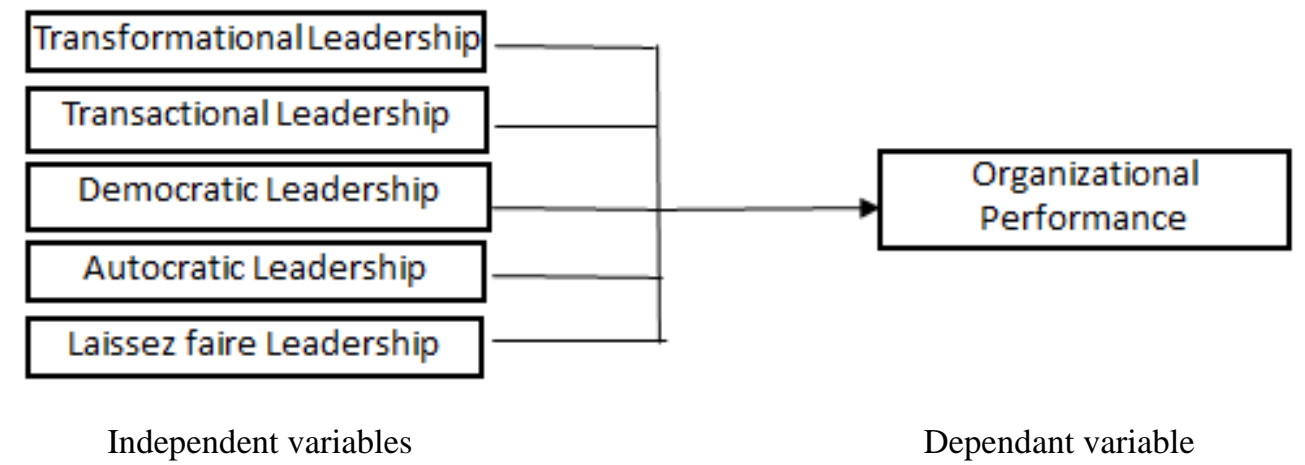

Figure 1 Research model

\subsection{Data Collection Method}

The required data was collected with the help of a structured questionnaire. The questionnaire had a range of questions related to various leadership styles and the respondents were asked to mark the option that best described the leadership style in their organization. The questionnaires were distributed to 150 respondents. After ensuring the reliability and integrity of the data, 120 questionnaires were selected. Convenient sampling method was used to select the respondents and the questionnaires were distributed online. The respondents belong to UAE based Organization.

\subsection{Hypotheses}

In order to achieve the objectives of this paper, two sets of hypotheses are formulated and examined. The first set of hypotheses assess the relationship between leadership styles and organizational performance. This proposition can explain if leadership styles and organizational performance is directly or indirectly related. The second set of hypotheses examines if leadership styles have a significant effect on organizational performance. The two sets of hypotheses are given below. 
$\mathrm{H}_{01-}$ There is no relationship between leadership styles and organizational performance.

$\mathrm{H}_{11}$ - There is a relationship between leadership styles and organizational performance.

$\mathrm{H}_{02}$-Leadership style does not have a significant impact on organizational performance.

$\mathrm{H}_{12}$ - Leadership styles have a significant impact on organizational performance.

\subsection{Limitations}

It has been observed that organization usually pursues different leadership styles and it is difficult to get the data related to what was the effect of each leadership style on the performance of the organization.

\section{DISCUSSION AND FINDINGS}

The first part of the study is to understand the relationship of leadership styles on organizational performance. Pearson's coefficient of correlation is used to determine the relationship. From Table 1, it can be seen that Democratic (r=0.719) and Transformational leadership style $(\mathrm{r}=0.697)$ has a high positive correlation with organizational performance. This implies that these two styles of leadership helps in improving the organizational performance. Autocratic ( $\mathrm{r}=-0.529)$ and Laissez faire leadership styles $(\mathrm{r}=-0.631)$ is seen to have high negative correlation with organizational performance and Transactional leadership style $(\mathrm{R}=-0.331)$ is seen to have moderate negative correlation with organizational performance. This implies that these leadership styles are not effective in achieving organizational performance. This analysis shows that leadership styles do have a positive and negative relationship with organizational performance. Hence the null hypothesis stating that there is no relationship between leadership styles and organizational performance is rejected and alternate hypothesis stating that there is a relationship between leadership styles and organizational performance is accepted.

Table 1 Correlation between leadership style and organizational performance

\begin{tabular}{|l|c|c|c|}
\hline \multicolumn{1}{|c|}{ Variables } & Mean & SD & $\begin{array}{c}\text { Correlation } \\
\text { coefficient (r) }\end{array}$ \\
\hline Organizational performance & 20.011 & 1.416 & 1 \\
\hline Democratic & 4.965 & 1.824 & 0.719 \\
\hline Autocratic & 2.352 & 0.632 & -0.529 \\
\hline Laissez faire & 2.419 & 1.549 & -0.631 \\
\hline Transformational & 4.791 & 0.428 & 0.697 \\
\hline Transactional & 1.739 & 1.153 & -0.331 \\
\hline
\end{tabular}

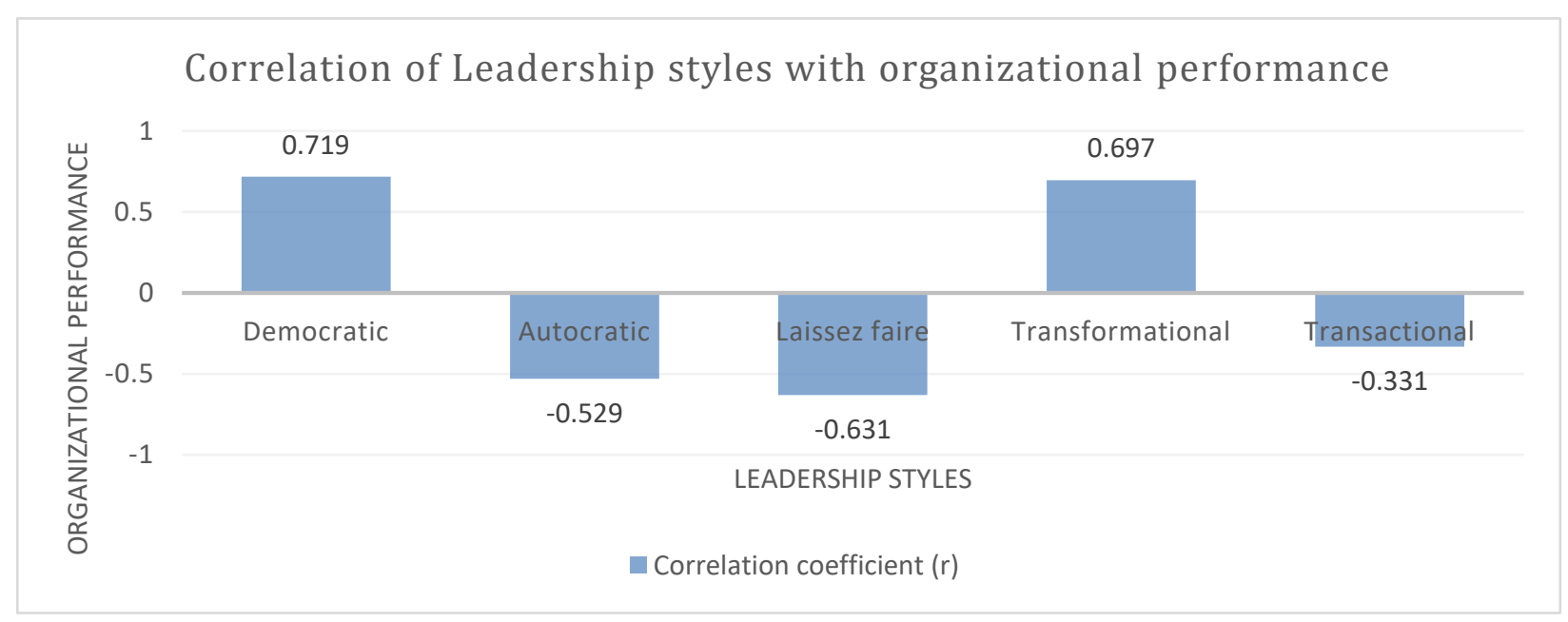

Figure 2 Graph representing Correlation between leadership styles and organizational performance 
The first part of the study established that leadership styles and organizational performance are related. The second part of the study examines the impact or effect of leadership styles on organizational performance. Multiple linear regression analysis is used to determine this. Table 2 shows that the $\mathrm{R}$ square value is 0.254 . This implies that from this model, $25 \%$ of variability of organizational performance is explained by the leadership styles. Table 3 is used to determine the effectiveness of the model by assessing if the independent variables are effective in predicting the dependant variable. From table 2 it can be seen that the $\mathrm{p}$ value is 0.028 which is less than $0.05,(\mathrm{p}<0.05)$ and this implies that this model is effective in predicting the effect of leadership styles on organizational performance.

Table 2 Model summary

\begin{tabular}{|c|c|c|c|c|}
\hline Model & R & R Square & Adjusted R Square & $\begin{array}{c}\text { Std Error of the } \\
\text { estimate }\end{array}$ \\
\hline 1 & 0.483 & 0.254 & 0.198 & 2.93 \\
\hline
\end{tabular}

Table 3 ANOVA test summary

\begin{tabular}{|l|c|c|c|c|c|}
\hline \multicolumn{1}{|c|}{ Model } & Sum of Squares & Df & Mean Square & F & Sig \\
\hline 1. Regression & 32.081 & 6 & 5.501 & 2.543 & 0.028 \\
\hline Residual & 108.075 & 52 & 2.082 & & \\
\hline Total & 141.522 & 57 & & & \\
\hline
\end{tabular}

Table 4 helps to determine the significance and impact of leadership styles on organizational performance. From this table, it can be seen that Autocratic leadership style (beta=-0.137, $\mathrm{t}=-2.371$, sig=0.014) and Laissez faire leadership style (beta=-0.062, $\mathrm{t}=-2.138$, sig $=0.038$ ) has a negative effect on organizational performance. They have a significant negative impact on organizational performance as their sig value (0.014 and 0.038$)$ is less than 0.05 which implies that it is significant. It is seen that transactional leadership style (beta $=0.049, \mathrm{t}=0.273$, sig $=0.531$ ) has a negative impact on organizational performance. However, it does not have a significant effect on organizational performance as its sig value (0.531) is greater than 0.05 which implies that it is not significant. It is seen that transformational leadership style (beta $=0.207, \mathrm{t}=0.481$, sig $=0.025$ ) and democratic leadership style (beta $=0.371, \mathrm{t}=0.295$, sig $=0.014$ ) has a positive and significant impact on organizational performance.

In the graph below, beta value is a measure of how strongly each independent variable influences the dependent variable. It can be seen that Democratic leadership has the maximum positive impact on organization performance with a beta value of 0.372 followed by transformational leadership with a beta value 0.207. Autocratic leadership (beta=-0.137) is seen to have the most negative impact. Hence the null hypothesis $\left(\mathrm{H}_{21}\right)$ is rejected and alternate hypothesis $\left(\mathrm{H}_{22}\right)$ is accepted.

Table 4 Beta Coefficients

\begin{tabular}{|l|c|c|c|c|c|}
\hline \multirow{2}{*}{ Variables } & Unstandardized Coefficients & Standardized Coefficients & \multirow{2}{*}{ t } & \multirow{2}{*}{ Sig } \\
\cline { 2 - 6 } & $\mathbf{B}$ & $\begin{array}{c}\text { Std } \\
\text { Error }\end{array}$ & Beta & & \\
\hline 1. (Constant) & 33.041 & 3.033 & & 6.859 & 0 \\
\hline Democratic & 0.543 & 0.108 & 0.372 & 0.295 & 0.014 \\
\hline Autocratic & -0.473 & 0.324 & -0.137 & -2.371 & 0.013 \\
\hline Laissez faire & -0.499 & 0.067 & -0.062 & -2.138 & 0.038 \\
\hline Transformational & 0.459 & 0.095 & 0.207 & 0.481 & 0.025 \\
\hline Transactional & 0.061 & 0.109 & 0.049 & 0.273 & 0.531 \\
\hline
\end{tabular}




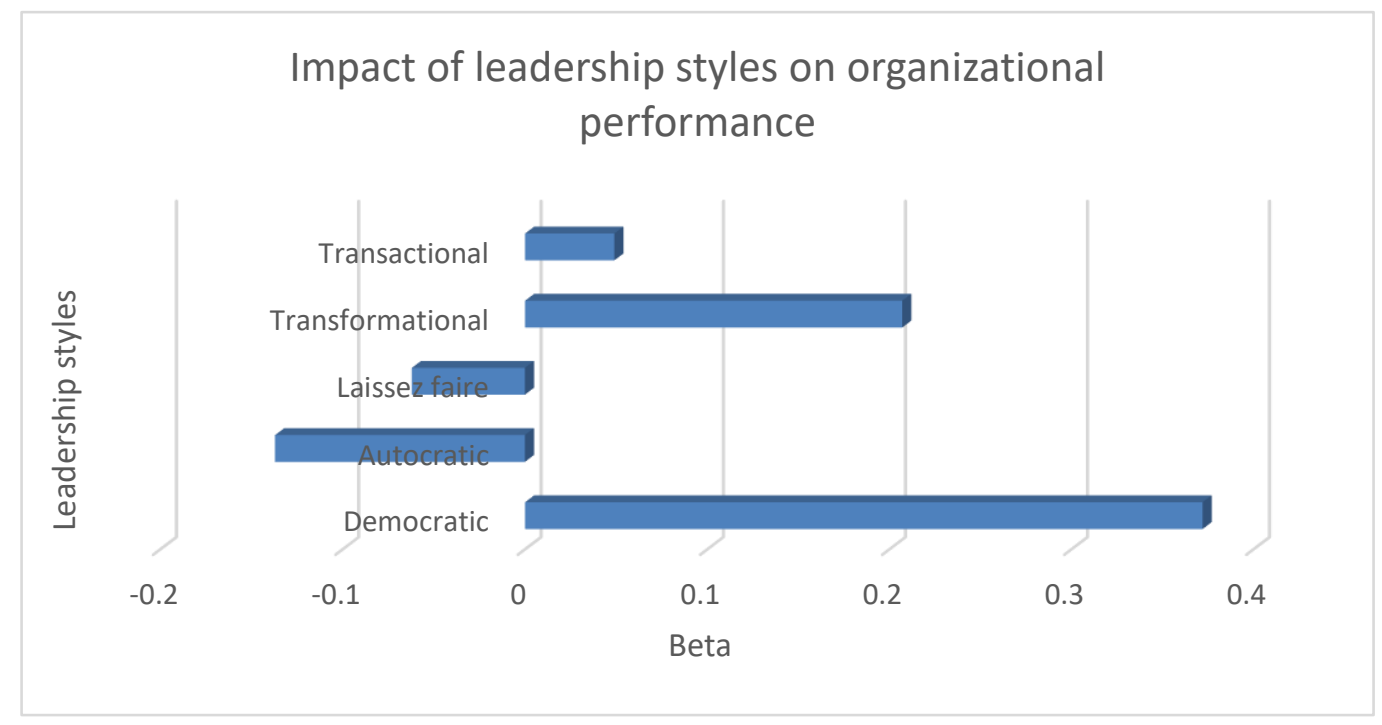

Figure 3 Graph representing the impact of leadership styles on organizational performance

\section{CONCLUSION AND RECOMMENDATIONS}

\subsection{Conclusion}

This study was conducted with the aim of identifying the impact of leadership styles on organizational performance. Pearson's correlation coefficient and Regression analysis was used to investigate the impact. From the analysis, it can be concluded that Democratic and Transformational leadership style has a positive and significant impact on organizational performance. This is because democratic leadership is a participative leadership style where the leader is receptive towards the suggestions and feedback of the employees. Transformational leadership motivates the employees to do better hence these leadership styles enhances organizational performance. It was observed that Autocratic and Laissez faire leadership has negative and significant impact on organizational performance. In Autocratic leadership style, leaders usually do not give employees any decision making power and often micro manages them where as Laissez faire leaders are very laid back and do not give timely feedback to employees. Transactional leadership style was found to have a negative effect on the organisational performance. However, they did not show a significant impact on the organisational performance. This is because Transactional leaders use rewards and punishments to achieve organizational goals and this method is not effective in all situations.

\subsection{Recommendations}

Based on the Findings, the following recommendations are given. It is recommended that managers adopt Democratic or Transformational leadership styles as they show a significant positive relation to organizational performance. Transactional leadership style is seen to have a positive but non-significant impact on organizational performance. Hence, this style of leadership would be useful only while managing a workforce who are motivated by a reward and punishment method. Managers should refrain from adopting Laissez faire and Autocratic leadership styles as they had a significant negative influence on organizational performance

\section{REFERENCES}

[1] Avolio, B. J. \& Yammarino, F. J., 2013. Transformational and Charismatic Leadership: The Road Ahead. 10 ed. Britain: Emerald Group Publishing. Blanchard, K., 2003. Servant Leader. 1 ed. n.d: Thomas Nelson Inc. 
[2] Bass, B.M. (1990). Bass and Stogdill's handbook of leadership: Theory, research, and managerial applications, New York: Free Press

[3] Bass, B.M., Avolio, B.J. (1991). The multi-factor leadership questionnaire, Palo, Alto, CA: Consulting Psychologists Press

[4] Conger, J. A. \& Kanungo, R. N., 1998. Charismatic Leadership in Organizations. n.d ed. New york: SAGE publications.

[5] Daft, R., 2008. The Leadership Experience. 4 ed. USA: Thomson Corporation.

[6] Fiedler, F.E. (1967). A Theory of Leadership Effectiveness. New York: McGraw-Hill

[7] Fiedler, F.E. (1996). Research on Leadership Selection and Training: One View of the Future, Administrative Science Quarterly, 41: 241-50.

[8] Flippo, E. B. \& Munsinger, G. M. (1999). Management. Boston: Allyn and Bacon, Inc

[9] Fry, L. W. (2003). Towards a Theory of Spiritual Leadership. The Leadership Quarterly, 14, 693-727.

[10] Gaikar V. B. and Mithani D.M. (2017) 'Business Economics-II', Himalaya Publishing House, Mumbai

[11] Gaikar V. B. and Sameer A Lakhani (2019), 'Study of Demographic Variables on Financial Goal of Urban Individuals' in International Journal of Research, Vol. 9 (1), July-December 2019, Pp. $24-34$

[12] Gaikar Vilas B. (2014) 'The Success of Poverty Alleviation Programmes in India: A Case Study of Thane district' in Humanities and Social Sciences Review

[13] Gaikar Vilas B., 'An empirical study of Co-operatives in India: With reference to the FiveYear Plans' in 'The Business and management review' Volume-5, Number-4, (2015), Pp.25-29

[14] Gaikar Vilas B., 'Can Poverty alleviation possible in India? A study of Thane ${ }^{1}$ district' in 'North Asian International Research Journal of Social Science \& Humanities', Vol. 3, Issue 6, (2018), Pp.12-17

[15] Hardman, D. K. \& Hardman, D., 2009. Judgment and Decision Making: Psychological Perspectives. 1 ed. Britain: BPS Blackwell.

[16] House, R. J. \& Aditya, R. N. (1997). The Social Scientific Study of Leadership: Quo Vadis? Journal of Management, (23)3: 409-473.

[17] Jeremy M, Melinde .C \& Ciller V. (2012). Perceived leadership style and employee participation in a manufacturing company in the democratic republic of Congo, African journal of business management, .6(15), 5389-5398.

[18] John Kane, H. P., 2012. The Democratic Leader: How Democracy Defines, Empowers and Limits Its Leaders. 1 ed. U.K: OUP Oxford.

[19] Kane, J. \& Patapan, H., 2014. Good Democratic Leadership: On Prudence and Judgment in Modern Democracies. 1 ed. U.K: OUP Oxford.

[20] Koontz, H. \& Donnell, C. (1993). Introduction to Management. McGraw-Hill Inc., New York.

[21] Kouzes, J. M. \& Posner, B. Z., 2012. The Leadership ChLondon: Oxford University Press.

[22] Lee and Chuang (2009). The Impact of Leadership Styles on Job Stress and Turnover Intention: Taiwan Insurance Industry as an Example.www.hclee@ttu.edu.tw

[23] McGrath, G. R and MacMillan, I. C. (2000). Entrepreneurial Mindset: Strategies for Continuously Creating Opportunity in an Age of Uncertainty. Harvard Business School Press Books. 
[24] Mehra, A., Smith, B., Dixon, A., \& Robertson, B. (2006). Distributed Leadership in Teams: The Network of Leadership Perceptions and Team Performance. Leadership Quarterly, 17: 232-245. 33

[25] Messick, D. M. \& Kramer, R. M. (2004). The Psychology of Leadership: New Perspectives and Research. Lawrence Erlbaum Associates, Publishers. New Jersey.

[26] Meyer, G. D. and Heppard, K.A. (2000). Entrepreneurial Strategies: The Dominant Logic of Entrepreneurship. New York, NY: Irwin University Books.

[27] Nelson, D. L. \& Quick, J. C., 2013. Oallenge. 5 ed. San Francisco: John Wiley \& Sons.

[28] Purcell, J., Kinnie, N., Hutchinson, S., Rayton, B. \& Swart, J. (2004). Understanding the People \& Performance Link: Unlocking the Black Box. Research Report, Chartered Institute of Personnel and Development.

[29] Schein, E. H., 2010. Organizational Culture and Leadership. 4 ed. San Francisco: John Wiley \& Sons.

[30] Senge, P. (1990), The Fifth Discipline: The Art and Practice of the Learning Organization, Doubleday Currency, New York, NY.

[31] Stogdill, R.M. \& Coons, A.E. 1957. Leader Behavior its Description and Measurement. Ohio: Bureau of Business Research, The Ohio State University, 88, 1-27.

[32] Terry, L. D., 2015. Leadership of Public Bureaucracies: The Administrator as Conservator. 2 ed. U.K: Routledge,

[33] Van Knippenberg, B., van Knippenberg, D., De Cremer, D. \& Hogg, M.A. (2005). Research in leadership, self, and identify: A sample of the present and a glimpse of the future. The Leadership Quarterly, 16, 495 - 499

[34] Vilas Gaikar and Jacob Cherian (2020). 'An empirical study on impact of sustainabilityoriented total quality management practices on organizational performance in UAE based organization', International Journal of Mechanical and Production Engineering Research and Development (IJMPERD) ISSN (P): 2249-6890; ISSN (E): 2249-8001 Vol. 10, Issue 3, Jun 2020, Pp. 13667-13678

[35] Vroom, V. and Yetton, P. (1974). Leadership and Decision-Making. Pittsburgh, PA: University of Pittsburgh Press.

[36] Zhu, W., Chew, I. K. h. \& Spangler, W. D. (2005). CEO Transformational Leadership \& Organizational Outcomes: The Mediating Role of Human-Capital-Enhancing Human Resource Management. The Leadership Quarterly, 16(1): 39-52. 